Black, A. L., Kleiber, M., Butterworth, E. M., Brubacher, G. B. \& Kaneko, J. J. (I957). F. biol. Chem. 227, 537.

Chesworth, J. M. \& Smith, G. H. (1971). Proc. Nutr. Soc. 30, 47A.

Hanson, R. W. \& Ballard, F. J. (1967). Biochem. F. 105, 529.

Hardwick, D. C. (1966). Biochem. Y. 99, 228.

Hardwick, D. C., Linzell, J. L. \& Mepham, T. B. (1963). Biochem. F. 88, 213.

Heath, D. F. (1968). Biochem. F. rro, 313.

Katz, J. \& Wood, H. G. (1960). f. biol. Chem. 235, 2165.

Kronfeld, D. S., Mayer, G. P., Robertson, J. McD. \& Raggi, F. (1963). 7. Dairy Sci. 46, 559.

Landau, B. R. \& Katz, J. (I965). In Handbook of Physiology, Sect. 5, Adipose Tissue p. 253 [A. E. Renold and G. F. Cahill, Jr, editors]. Washington, D.C.: American Physiological Society.

Lindsay, D. B. (1970). In Physiology of Digestion and Metabolism in the Ruminant p. 438 [A. T. Phillipson, editor]. Newcastle upon Tyne: Oriel Press.

Linzell, J. L. \& Mepham, T. B. (1968). Biochem. 7. 107, 18.

McCarthy, J. (1970). The role of $\beta$-hydroxybutyrate in milk fat synthesis in ruminants. $\mathrm{PhD}$ Thesis, University of Leeds.

McClymont, G. L. (I95I). Aust. F. agric, Res, 2, 158.

Raafat, M. A., Verbeke, R. \& Peeters, G. (1963). Biochem. F. 88, 155.

Rook, J. A. F. \& Hopwood, J. B. (1970). F. Dairy Res. 37, 193.

Rook, J. A. F., Storry, J. E. \& Wheelock, J. V. (I965). F. Dairy Sci. 48, 745.

Smith, R. W. \& Glascock, R. F. (1969). F. Dairy Res. 36, 469.

Wood, H. G., Peeters, G. J., Verbeke, R., Lauryssens, M. \& Jacobson, B. (I965). Biochem. F. 96, 607.

\title{
Changes in the pattern of glucose metabolism in growth, pregnancy and lactation in ruminants
}

By D. B. Lindsay, Biochemistry Department, A.R.C. Institute of Animal Physiology, Babraham, Cambridge

The carbohydrate needs of pregnancy and lactation are of particular interest in ruminants because of their dependence on gluconeogenesis. The rate of gluconeogenesis (glucose entry rate) can therefore be determined by isotope dilution in fed or fasted ruminants. In sheep starved for $6 \mathrm{~d}$ the rate is about $\mathrm{I} 20-140 \mathrm{mg} / \mathrm{h}$ per $\mathrm{kg}^{0.75}$, which compares closely to values in fasted non-ruminants (Cowan, Vranic \& Wrenshall, 1969; Owen, Felig, Morgan, Wahren \& Cahill, 1969). The increased rate in fed ruminants may be related to either digestible energy (DE) or to protein intake (Judson \& Leng, I968), but over a wider range of rations and animals there is a much better relationship with DE than with protein intake (Lindsay, 1970). This is probably because the DE intake determines the rate of volatile fatty acid production and thus, also, the rate of synthesis of microbial protein, which probably accounts for most of the protein available to ruminants (Leng, 1970). It is assumed that the major precursors of glucose are propionate and glycogenic amino acids.

In pregnant sheep, Steel \& Leng (1968) showed that the glucose entry rate is determined more by the food intake than by the stage of pregnancy. It is possible that on a fixed ration there is a slight increase in the glucose entry rate as pregnancy develops, but such increase is small compared with the effect of increased feed intake. When ewes were offered lucerne $a d$ lib. they increased their intake markedly in late pregnancy; glucose entry rate was increased but not as much as might be 
expected from the increase in DE intake. Starved pregnant ewes had no greater entry rate than that of starved non-pregnant ewes.

In lactation, glucose entry rate is greatly increased. Bergman \& Hogue (r967) found in sheep a value of about $650 \mathrm{mg} / \mathrm{h}$ per $\mathrm{kg}^{0.75}$ at peak lactation and even at Io weeks, when lactation was declining, the value was $490 \mathrm{mg} / \mathrm{h}$ per $\mathrm{kg}^{0.75}$. J. R. Mercer and E. L. Miller (personal communication) found a similar value-about $600 \mathrm{mg} / \mathrm{h}$ per $\mathrm{kg}^{0.75}$. Annison \& Linzell (1964) reported values in goats of about $74^{\circ} \mathrm{mg} / \mathrm{h}$ per $\mathrm{kg}^{0.75}$ in early lactation and $55^{\circ} \mathrm{mg} / \mathrm{h}$ per $\mathrm{kg}^{0.75}$ in late lactation. E. F. Annison, J. L. Linzell and R. Bickerstaffe (personal communication) have found values in cows of about $820 \mathrm{mg} / \mathrm{h}$ per $\mathrm{kg}^{0.75}$ and, in high-yielding Friesians, Brown \& Lindsay ( 1966 ) found values as high as $990 \mathrm{mg} / \mathrm{h}$ per $\mathrm{kg}^{0.75}$. Only in the studies of J. R. Mercer and E. L. Miller was food intake measured. The DE intake could have resulted in an entry rate as high as $800 \mathrm{mg} / \mathrm{h}$ per $\mathrm{kg}^{0.75}$, assuming in lactating sheep a similar relationship between $\mathrm{DE}$ intake and glucose entry rate as that seen in non-lactating sheep. In goats, a $24-\mathrm{h}$ fast results in a fall in glucose entry rate to $219 \mathrm{mg} / \mathrm{h}$ per $\mathrm{kg}^{0.75}$ and a $50 \%$ fall in milk yield (Annison, Linzell \& West, 1968). Kronfeld \& Raggi (1964) found a similar entry rate in fasted cows. These values are probably little greater than would be found in fasted non-lactating goats and cows. Increase in food intake is clearly a major determinant of increased glucose production in pregnancy and lactation. There is no evidence so far of an increase in the efficiency of conversion of nutrients to glucose.

\section{Origin of glucose produced}

Although all the techniques that have been used for assessing the relative importance of propionate and protein as sources of glucose have limitations (Leng (1970) and Lindsay (1970) discuss some of these), it seems that in non-pregnant sheep propionate does not contribute more than $50 \%$ of glucose synthesized (Bergman, Roe \& Kon, I966; Leng, Steel \& Luick, I967). Amino acids contribute, at most, $25 \%$ (Wolfe, Bergman \& Williams, 1971).

In pregnancy, the foetus has a substantial demand for protein. The results of Curet, Crenshaw, Mann, Abrams \& Barron (1970) suggest that near term, the pregnant uterus and its contents may be removing $40 \mathrm{~g}$ amino acid/24 h. Thus, even if mobilizing of protein of maternal tissues of the fed sheep is normal in late pregnancy, as Naismith ( 1969 ) finds in the rat, it is possible that little extra protein is available for gluconeogenesis. In fact, Nolan \& Leng (1970) found no appreciable change in urea entry rate in pregnant compared with non-pregnant sheep on adequate feed intake. Interpretation is complicated by the fact that only part of the urea entry is derived from the catabolism of amino acids. Ford \& Reilly (1970), in experiments with mixed ${ }^{14} \mathrm{C}$-labelled amino acids, report no significant change in the proportion of glucose derived from amino acids in pregnant sheep. J. W. Steel, however, (cited by Leng, 1970) does find an increased propionate contribution in pregnancy.

In lactating goats, Mepham \& Linzell (Ig66) have shown that amino acid uptake approximates milk protein output and thus there is a removal by the udder of some 
$60 \mathrm{~g}$ amino acid daily. A decreased dependence on amino acids for glucose synthesis would, therefore, not be unexpected. Hunter \& Millson (1964) estimated that in cows $12 \%$ of milk lactose was derived from amino acids. Egan \& Black (1968) estimated about $8 \%$ of glucose in cows was derived from glutamate, whereas J. R. Mercer and E. L. Miller (unpublished) estimated that $20 \%$ of glucose in lactating sheep is derived from glutamate. In the same work, these authors found $40-60 \%$ of glucose derived from propionate.

It seems then, from the limited evidence available, that the relative contributions of propionate and amino acids to glucose synthesis are not appreciably changed in lactation. There is perhaps one further factor that should be considered. The highest rates of glucose entry reported are those in lactating Friesian cows. These animals were given a high proportion of maize in the ration, which may result in significant amounts of starch escaping fermentation in the rumen. There may therefore be a significant fraction of glucose being absorbed from the gastrointestinal tract.

These results imply that as more substrate (amino acid or propionate) is supplied to the liver, more glucose is synthesized. This is consistent with the results of Lindsay \& Williams ( $197 \mathrm{I}$ ). When $100 \mathrm{~g}$ casein/d was infused in the abomasum of sheep, superimposed on rations of varying $\mathrm{DE}$, the (approximately constant) increase in glucose entry rate was independent of the initial value. In the isolated perfused sheep liver, J. L. Linzell, B. P. Setchell and myself found that propionate would increase gluconeogenesis but only to a rate about half the glucose entry rate observed in vivo in non-pregnant non-lactating sheep. This maximal rate was reached at a propionate concentration well below I mmol/l. Addition of a mixture of glycogenic amino acids had very little effect on gluconeogenesis; however, a marked stimulation was observed on further addition of glucagon. Preliminary results suggest that glucagon also increases gluconeogenesis from propionate. In contrast, insulin is known to inhibit gluconeogenesis in sheep (West \& Passey, I 967). Both plasma insulin and glucagon are known to increase in sheep after feeding (Bassett, I97I) but the relative effectiveness of the two hormones on gluconeogenesis in vivo has still to be demonstrated. It is also possible that the effect may be modified in pregnancy or lactation. Although it is plausible that the availability of substrate is the major controlling factor in gluconeogenesis, other possibilities are not excluded.

\section{Glucose utilization}

Pregnancy. As Leat (1971) has emphasized, glucose is the major energy source for the foetus and it is used also for synthesis of fructose, glycogen and fatty acids. It is usually suggested that 8-9 g glucose/kg daily is removed by the foetus near term $(3 \circ \%$ of glucose entry rate). Probably this underestimates glucose removal since in unpublished work by B. P. Setchell, J. M. Bassett, N. T. Hinks and N. McC. Graham, the average glucose uptake by the uterus and contents in pregnant ewes was about $70 \%$ of the measured glucose entry rate. This may well be more reliable than earlier estimates since ( 1 ) measurements were made in conscious ewes; (2) 
glucose entry rate, uterine arteriovenous difference and blood flow rates were made in the same animal; (3) the requirements of the uterus itself had not been included in previous estimates.

With a removal of glucose of this order by the uterus, glucose utilization by other maternal tissues should be reduced. Studies on glucose oxidation are consistent with this. There is no difference in the proportion of $\mathrm{CO}_{2}$ derived from glucose in pregnant and non-pregnant ewes (Bergman, 1963; Ford \& Reilly, 1970). In the work of Setchell and his colleagues, the uterus and its contents produced about I $\mathrm{mmol} \mathrm{CO} / \mathrm{min}$ from glucose, which is more than $70 \%$ of total glucose oxidized by the ewe. Glucose contribution to $\mathrm{CO}_{2}$ is thus, for extra-uterine tissues, reduced from $10 \%$ to probably $2 \%$ or less in late pregnancy. A reduction of this order is not improbable since obligatory carbohydrate utilization in non-pregnant ruminants may be quite small. For example in sheep brain, the average arteriovenous difference between artery and superior sagittal sinus is about $6 \mathrm{mg} / \mathrm{I00} \mathrm{ml} \mathrm{(McClymont} \mathrm{\&}$ Setchell, I956) and in goat brain about $8 \mathrm{mg} / \mathrm{roo} \mathrm{ml}$ (Oyler, Jones \& Goetsch, 1970). Blood flow in sheep brain is about $35 \mathrm{ml} / \mathrm{roo} \mathrm{g}$ per min (B. P. Setchell and G. M. H. Waites, personal communication). Thus, uptake is about $2-2.5 \mathrm{mg} / \mathrm{roo} \mathrm{g}$ per min. Weight of brain and spinal cord is about $160 \mathrm{~g}$ (Wallace, 1948), and uptake is about $3^{-4} \mathrm{mg} / \mathrm{min}$ or $5^{-6} \%$ of glucose entry rate. This is very similar to glucose utilization by the testis in rams (about $3 \mathrm{mg} / \mathrm{min}$ ) (Setchell \& Waites, 1964). Although brain and testis are predominantly glucose-dependent, in relation to total glucose output the demand by these tissues is small. Bergman, Katz \& Kaufman, (1970) have shown that the splanchnic area has an uptake about $20 \%$ of the glucose entry rate. This may be because of the high rate of turnover of intestinal mucosa (Fisher \& Parsons, 1949). Even if much of this is therefore a specific need, total specific carbohydrate requirement need be no more than $25 \%$ of glucose entry rate in the nonpregnant ewe.

In non-ruminants there are indications that pregnancy decreases glucose utilization by maternal tissues (Freinkel, Herrera, Knopp \& Ruder, 1970). Progesterone and oestrogens could be involved in this diabetogenic effect. Cheng \& Yang (1970) have shown that both steroids have diabetogenic properties in rats. Dunn, Hopwood, House \& Faulkner ( 1968 ) have shown in ewes that there was a threefold rise in progesterone in the late luteal phase compared with oestrus. There was a nonsignificant rise in glucose entry rate and a significant rise in plasma glucose. In late pregnancy, plasma progesterone may be three times greater than this (Bassett, Oxborrow, Smith \& Thorburn, 1969). Other hormones may also play a part in limiting glucose utilization by extra-uterine tissues. The significance of hormones produced by the placenta is that they are not subject to feedback regulation, for example by nutritional influences (Frienkel et al. i 970 ).

Lactation. Demand for glucose by the udder is considerably more than is required to produce milk lactose. Annison \& Linzell (1964) found uptake by the goat udder was $60-85 \%$ of the glucose entry rate. In cows, they found $70-90 \%$ of glucose entry is removed by the udder in Friesians although the proportion is rather less $(20-55 \%)$ in Jerseys (unpublished work).

$3 \circ(3) 6$ 
About $50-60 \%$ of this glucose uptake is accounted for by milk lactose in goats and about $60-70 \%$ in Friesian cows. Most of the remainder forms triglyceride glycerol or is oxidized to $\mathrm{CO}_{2}$. Since the specific activity of lactose in isotope infusion experiments rarely exceeds $80 \%$ that of blood glucose, some of the galactose may be derived from other sources. However, there is also evidence (Linzell, 1968) that some of the amino acids used by the udder are synthesized in situ. Probably these interchanges reflect isotope exchange in the tricarboxylic acid cycle. It is now well established that glucose is not used for fatty acid synthesis in the ruminant mammary gland.

The large mammary uptake of glucose might result in substantial reduction in glucose uptake by other tissues. The percentage of $\mathrm{CO}_{2}$ derived from glucose is similar in lactating cows to that of non-lactating ruminants $(9-10 \%)$, though few studies have been made in dry cows. Although glucose oxidation by the udder is large in proportion to its size, only approximately one-third of the total glucose oxidized to $\mathrm{CO}_{2}$ is oxidized in the udder (E. F. Annison, J. L. Linzell and R. Bickerstaffe, unpublished). There is probably only a moderate fall in glucose oxidation by extra-mammary tissues; this represents a real contrast with the situation in pregnancy.

Hardwick, Linzell \& Price (1961) showed that, in the perfused udder, glucose was essential for secretion of milk and Linzell ( 1967 ) showed that infusion of glucose could raise the hourly milk yield in goats with a low blood glucose. It is striking therefore that the results of Annison, Linzell and Bickerstaffe show that as lactation progresses, there is a fall in uptake of glucose by the udder even with a high glucose entry rate. Mammary blood flow was also well maintained, so that clearly something other than substrate availability is involved.

Growth. We have to distinguish between gain in protein and gain in fat. There is evidence that in ruminants glucose may limit the rate of fat synthesis although it is not used direct to supply the carbon (Lindsay, 1970). I suspect, however, that fat synthesis de novo is not of great significance in ruminants. On the possible role of glucose in protein synthesis, we have no direct information. In suckling ruminants, glucose availability is high but falls once rumination has developed (Jarrett, Jones $\&$ Potter, r964). No studies have been made comparing growth rate with glucose availability. Cunningham (1968) tried increasing insulin secretion in young lambs, but found no effect on growth rate or carcass composition. It is difficult to interpret these results because of the powerful feedback controls on hormone secretion rates. It might be of interest to use the technique described by Ørskov \& Benzie (I 969 ) to see if increased growth rates could be obtained when glucose was supplied via the abomasum. It is probable that a specific requirement for glucose will be found in any situation of intense anabolic activity; whether it is ever rate-limiting for growth will not be easy to demonstrate.

\section{REFERENCES}

Annison, E. F. \& Linzell, J. L. (1964). F. Physiol., Lond. 175, 372.

Annison, E. F., Linzell, J. L. \& West, C. E. (1968). J. Physiol., Lond. 197, 445,

Bassett, J. M. (I971). Aust. F. biol. Sci. (In the Press.) 
Bassett, J. M., Oxborrow, T., Smith, I. D. \& Thorburn, G. D. (1969). F. Endocr. 45, 449.

Bergman, E. N. (1963). Am. F. Physiol. 204, 147.

Bergman, E. N. \& Hogue, D. E. (1967). Am. F. Physiol. 213, 1378.

Bergman, E. N., Katz, M. \& Kaufman, C. F. (1970). Am. F. Physiol. 2r9, 785.

Bergman, E. N., Roe, W. E. \& Kon, K. (rg66). Am. F. Physiol. 21r, 793.

Brown, R. E. \& Lindsay, D. B. (I966). Fedn Proc. Fedn Am. Socs exp. Biol. 25, 543.

Cheng, K.-K. \& Yang, M. M.-P. (1970). Q. Il exp. Physiol. 55, 83.

Cowan, J. S., Vranic, M. \& Wrenshall, G. A. (1969). Metabolism 18, 3 I9.

Cunningham, H. M. (1968). Can. F. comp. Med. 32, 430.

Curet, L. B., Crenshaw, C., Mann, L., Abrams, R. H. \& Barron, D. H. (г97o). Q. fl exp. Physiol. 55, 253.

Dunn, T. G., Hopwood, M. L., House, W. A. \& Faulkner, L. C. (1968). 7. Anim. Sci. 27, 1785.

Egan, A. R. \& Black, A. L. (1968). \%. Nutr. 96, 450.

Fisher, R. B. \& Parsons, D. S. (1949). F. Physiol., Lond. 1xo, 36.

Ford, E. J. H. \& Reilly, P. E. B. (1970). Res. vet. Sci. Ir, 575.

Freinkel, N., Herrera, E., Knopp, R. H. \& Ruder, H. J. (1970). In Early Diabetes p. 205 [R. A. CameriniDavalos and H. S. Cole, editors]. London: Academic Press.

Hardwick, D. C., Linzell, J. L. \& Price, S. M. (r96r). Biochem. F. 8o, 37.

Hunter, G. D. \& Millson, G. E. (1964). Res. vet. Sci. 5, I.

Jarrett, I. G., Jones, G. B. \& Potter, B. J. (I 964). Biochem. F. 90, 189.

Judson, G. J. \& Leng, R. A. (1968). Proc. Aust. Soc. Anim. Prod. 7, 354.

Kronfeld, D. S. \& Raggi, F. (1964). Am. f. Physiol. 206, 109.

Leat, W. M. F. (1971). Proc. Nutr. Soc. 30, 236.

Leng, R. A. (1970). Adv. vet. Sci. 14, 209.

Leng, R. A., Steel, J. W. \& Luick, J. R. (1967). Biochem. F. 103, 785.

Lindsay, D. B. (I970). In Physiology of Digestion and Metabolism in the Ruminant p. 438 [A. T. Phillipson, editor]. Newcastle upon Tyne: Oriel Press.

Lindsay, D. B. \& Williams, R. L. (I97I). Proc. Nutr. Soc. 30, 35A.

Linzell, J. L. (1967). J. Physiol., Lond. r90, 347.

Linzell, J. L. (1968). Proc. Nutr. Soc. 27, 44.

McClymont, G. L. \& Setchell, B. P. (1956). Aust. F. biol. Sci. 9, 184.

Mepham, T. \& Linzell, J. L. (1966). Biochem. F. IOI, 76.

Naismith, D. J. (I969). Proc. Nutr. Soc. 28, 25.

Nolan, J. V. \& Leng, R. A. (1970). Br. F. Nutr. 24, 905.

Owen, O. E., Felig, P., Morgan, A. P., Wahren, J. \& Cahill, G. F. Jr (1969). Y. clin. Invest. 48, 574.

Ørskov, E. R. \& Benzie, D. (1969). Br. J. Nutr. 23, 4 I5.

Oyler, J. M., Jones, K. L. \& Goetsch, D. D. (1970). Am. F. vet. Res. 31, I801.

Setchell, B. P. \& Waites, G. M. H. (1964). F. Physiol., Lond. I7r, 4 II.

Steel, J. W. \& Leng, R. A. (1968). Proc. Aust. Soc. Anim. Prod. 7, 342.

Wallace, L. R. (1948). F. agric. Sci., Camb. 38, 243.

West, C. E. \& Passey, R. F. (1967). Biochem. F. 102, 58.

Wolfe, J. E., Bergman, E. N. \& Williams, H. H. (I97I). Fedn Proc. Fedn Am. Socs exp. Biol. 30, 404, Abstr.

Chairman : E. A. Newsholme, MA, PhD, Department of Zoology, University of Oxford

\section{Effects of dietary carbohydrate on lipid metabolism in primates}

\section{By I. Macdonald, Department of Physiology, Guy's Hospital Medical School, London $S E_{\mathrm{I}}{ }_{9} R T$}

Since Lawes \& Gilbert ( 1852 ) reported to the British Association that carbohydrates given to animals can be converted into depot fat, the knowledge that this conversion is widely present is generally accepted. Even the obese lady is aware of 